\section{Antitranspirants Partially Mitigate Auxin Herbicide Injury on Tomato Plants}

\author{
Michele R. Warmund, David H. Trinklein, Mark R. Ellersieck, and \\ Reid J. Smeda \\ Division of Plant Sciences, University of Missouri, Columbia, MO 65211
}

Additional index words. dicamba, Moisture-Loc, Solanum lycopersicon, 2,4-D, Wilt-Pruf

\begin{abstract}
The use of dicamba and 2,4-D products on herbicide-tolerant crops has resulted in numerous cases of off-target movement and injury to sensitive plants, including tomato (Solanum lycopersicon $\mathbf{L}$.). Two greenhouse studies were conducted to determine whether 'Big Beef' ('BB') or 'Florida 91' ('FL') tomato plants pretreated with an antitranspirant, including Moisture-Loc (ML) at $100 \mathrm{~mL} \cdot \mathrm{L}^{-1}$, TransFilm (TF) at $50 \mathrm{~g} \cdot \mathrm{L}^{-1}$, or Wilt-Pruf (WP) at $100 \mathrm{~mL} \cdot \mathrm{L}^{-1}$, mitigated injury from synthetic auxin herbicides. Dicamba or 2,4-D was applied at a rate corresponding to $1 / 200$ of the manufacturer's labeled rate of $0.56 \mathrm{~kg}$ ae/ha or $1.06 \mathrm{~kg} \mathrm{ae} / \mathrm{ha}$, respectively. At 2 weeks after treatment (WAT), plants treated with ML or WP before either herbicide exhibited injury symptoms, but they were always less severe than those treated with the herbicide alone for both cultivars. However, shoot length measurements indicated that none of the antitranspirants consistently provided protection against herbicide injury at 2 WAT. By 12 WAT, ML or WP used before either herbicide increased the number of live reproductive organs compared with dicamba or 2,4-D alone for both cultivars. Floral abortion on tomato plants was also reduced when ML or WP was applied before an herbicide treatment by 12 WAT. Although WP and ML did not provide complete protection against synthetic auxin herbicide injury, the concept of using film-forming barriers may be useful in mitigating some of the short-term effects of drift on plants.
\end{abstract}

Auxin herbicides have been registered for postemergence control of broadleaf weeds in agricultural crops for more than 50 years (Peterson et al., 2016). Since their initial development, different formulations of auxin herbicides, such as 2,4-D and dicamba, were created to decrease their volatility in the environment (Sosnoskie et al., 2015). The diglycolamine salt of dicamba and choline salt of 2,4-D choline are two formulations that have been used on genetically modified soybeans and cotton in production areas where longterm use of glyphosate has resulted in resistant weed species (Gage et al., 2019). Although these auxin herbicides were formulated for reduced off-target movement via particle drift and volatility, injury occurs on sensitive crops at very low rates (Culpepper et al., 2018; Knezevic et al., 2018; Kruger et al., 2012; Mohseni-Moghadam and Doohan, 2015). Drift reduction agents, ambient temperature, wind speed, nozzle type, and boom height at the time of application influence drift, whereas volatilization is affected by air temperature, relative humidity, and

Received for publication 30 Mar. 2021. Accepted for publication 28 May 2021.

Published online 16 July 2021.

Contribution from the Missouri Agricultural Station project 322 .

M.R.W. is the corresponding author. E-mail: warmundm@missouri.edu.

This is an open access article distributed under the CC BY-NC-ND license (https://creativecommons. org/licenses/by-nc-nd/4.0/) vapor pressure (Alves et al., 2017; Bish et al., 2019; Egan and Mortensen 2012; Jones et al., 2019; Mueller and Steckel, 2019; Nordby and Skuterud, 1974; Sosnoskie et al., 2015).

In the eastern United States, tomatoes (Solanum lycopersicon L.) are a high-value crop often grown in close proximity to soybean or cotton fields where dicamba or 2,4-D may be used for weed control. In 2017, more than 2200 cases of alleged dicamba-related injury on several crops were investigated by regulatory agencies in various states (Bradley, 2017). In Missouri alone, 335 complaints of dicamba injury were reported, which included 7650 ha of tomato (Missouri Department of Agriculture, 2017).

Tomato plants are highly sensitive to dicamba and 2,4-D (Hemphill and Montgomery, 1981; Knezevic et al., 2018). Common symptoms of synthetic auxin herbicide injury include epinasty, deformed leaflets, split stems, plant stunting, flower and fruit loss, and malformed fruit with delayed maturity (Bauerle et al., 2015; Bennet, 1989; Hemphill and Montgomery, 1981; Robbins and Taylor, 1957). However, two important factors that influence the degree of injury are herbicide dosage and growth stage of sensitive plants. Kruger et al. (2012) estimated that dicamba applied with a nonionic surfactant and ammonium sulfate at $2.4,4.8$, and $13.3 \mathrm{~g}$ ae/ha resulted in $5 \%, 10 \%$, and $25 \%$ flower loss, respectively, when applied at an early vegetative stage on tomato. However, lower rates of dicamba $(1.5,2.7$, and $6.4 \mathrm{~g}$ ae/ha) caused similar percentages of flower loss when applied at early bloom. In other studies, 2,4$\mathrm{D}$ rates as low as 1.8 to $2.1 \mathrm{~g}$ ae/ha applied at early bloom reduced tomato yield and distorted fruit shape (Hemphill and Montgomery, 1981; Robbins and Taylor, 1957). Herbicide rates used in the previous two studies are consistent with those that can occur in off-target drift $(1 / 200=2.8 \mathrm{~g}$ ae/ha dicamba and $5.3 \mathrm{~g}$ ae/ha 2,4-D) (Egan and Mortensen, 2012; Kruger et al., 2012).

The severity of injury in response to auxin herbicides is also genotype-dependent. 'Glamour', 'Heinz 1439', 'Moreton Hybrid', and 'Roma' exhibited high tolerance to 2,4-D injury when 60 commercial tomato cultivars were sprayed at first bloom and evaluated (Coyne and Burnside, 1968). Also, three wild tomato accessions exhibiting less dicamba and 2,4-D injury than two commerciallyavailable cultivars ('Money Maker' and 'Better Boy') were recently identified, which may be used for the future development of herbicide-tolerant tomato plants (Zangoueinejad et al., 2019).

Most commercially grown tomato cultivars do not possess natural or engineered tolerance to dicamba and 2,4-D. Thus, solutions to mitigate injury concerns associated with off-target movement of these herbicides are needed for sensitive crops. One potential solution is the application of film-forming antitranspirant products. These antitranspirants provide a transient water-impermeable coating on plant surfaces and increase resistance to water vapor loss (Sutherland and Waters, 2002). Historically, film-forming polymers have been used as antitranspirants to reduce water loss of bareroot woody plants during postharvest handling or shipping (Englert et al., 1993), to minimize dehydration of fruits during cold storage (Plaut, 2008), to improve reestablishment of transplants (Goreta et al., 2007; Nitzsche et al., 1991), and to prevent plant infection from foliar pathogens (Han, 1990; Walters 1992). Three types of film-forming antitranspirants include a latex emulsion (ML, formerly known as Moisturin), an emulsion of polyethylenes and polyterpenes (TF), and a $\beta$-pinene polymer (WP), which have been labeled for various crops (Ondi Enterprises, 2020; Gordon, 2017; Wilt-Pruf Products, 2020).

Hummel (1990) reported that the $\beta$-pinene polymer antitranspirant was noninjurious to 'Early Giant' tomato and improved plant water status. However, film-forming products typically begin to lose their effectiveness in reducing transpiration $\approx 7$ to $10 \mathrm{~d}$ after application (Anderson and Kreith, 1978; Kreith et al., 1975). Temporary negative effects of filmforming antitranspirants include impaired gas exchange, decreased photosynthesis, and increased leaf temperature (Davenport et al., 1974; Davies and Kozlowski; 1974; Gale, 1961; Williamson, 1963). The layer of film formed at application degrades over time with plant growth (Albrigo, 1972; Funk, 1979).

Because tomato plants are highly sensitive to synthetic auxin herbicides, this species was selected as a model crop to ascertain if filmforming antitranspirants provide transient protection against dicamba and 2,4-D drift 
injury on two different cultivars with similar days to maturity ( 72 to $73 \mathrm{~d}$ ). The objective of this study was to determine if pretreating semideterminate 'Big Beef' ('BB') or determinate 'Florida 91' ('FL') tomato plants with ML, TF, or WP antitranspirant mitigated injury from dicamba or 2,4-D herbicides.

\section{Materials and Methods}

Expt. 1. 'BB' and 'FL' (Tomato Growers Supply, Fort Myers, FL) tomato seeds were sown in trays $(20 \times 27 \mathrm{~cm}$ size $)$ that contained a commercial growing medium of sphagnum moss, vermiculite, and perlite (ProMix BX; Premier Tech Horticulture, Québec, Canada) in late May 2019 and placed in a greenhouse maintained at $26^{\circ} \mathrm{C}$ day $/ 20^{\circ} \mathrm{C}$ night cycle under natural lighting. After germination, seedlings were transplanted at the two-leaf stage into $0.5-\mathrm{L}$ containers in the same growing medium, hand-watered as needed, and maintained in the greenhouse under conditions described earlier.

'BB' and 'FL' tomato plants had eight and seven leaves per plant, respectively, and were $\approx 25 \mathrm{~cm}$-tall with no visible floral buds when treated with an antitranspirant. Treatments included each antitranspirant alone, each herbicide alone, and each antitranspirant followed by either dicamba or 2,4-D. On 27 June, antitranspirant treatments, including ML (Zorro Technology, Clackamas, OR), TF (PBI Gordon, Shawnee, KS), or WP (Wilt-Pruf Products, Essex, CT) were applied by immersing the shoot growth in a product solution for $5 \mathrm{~s}$. Both ML and WP solutions $\left(100 \mathrm{~mL} \cdot \mathrm{L}^{-1}\right)$ were mixed according to the manufacturers' labeled concentration. Because a TF solution of $100 \mathrm{~mL} \cdot \mathrm{L}^{-1}$ caused phytotoxicity on tomato leaves in a preliminary test (M.R. Warmund, unpublished data), a lower concentration of $50 \mathrm{~mL} \cdot \mathrm{L}^{-1}$ was used for this study.

On 28 June, dicamba (Xtendimax with Vapor Grip; Bayer CropScience, St. Louis, MO) or 2,4-D (Enlist One with Colex-D; Dow AgroSciences, Indianapolis, IN) treatments were applied. Each herbicide was applied at $1 / 200$ the manufacturer's recommended use rate $(0.56 \mathrm{~kg}$ ae/ha dicamba or $1.06 \mathrm{~kg}$ ae/ha 2,4-D). Nontreated control plants (i.e., no antitranspirant and no herbicide) were also included for comparison. Herbicides were applied outdoors at $43 \mathrm{~cm}$ above the leaf canopy of tomato plants using a $\mathrm{CO}_{2}-$ pressurized backpack sprayer equipped with 8002 flat fan nozzles (TeeJet Technologies, Urbandale, IA) at $140 \mathrm{~L} \cdot \mathrm{ha}^{-1}$ and $193 \mathrm{kPa}$. Plants treated with dicamba, 2,4-D, and nontreated controls were isolated by treatment in three greenhouses $(\approx 15 \mathrm{~m}$-apart) to minimize herbicide cross-contamination among plants. One week later, plants were transplanted into 8.5-L polyethylene containers using the same growing medium just described and placed in a greenhouse at $26^{\circ} \mathrm{C}$ day $/ 20^{\circ} \mathrm{C}$ night cycle under natural light for duration of the study. Plants were hand-watered and fertilized as needed with $275 \mathrm{~g} \cdot \mathrm{L}^{-1}$ of $21 \mathrm{~N}-5 \mathrm{P}-20 \mathrm{~K}$ (Peters Excel; Everris NA, Dublin, OH). The experiment was a split plot design in a factorial arrangement $(2$ cultivars $\times 4$ antitranspirant treatments $\times 3$ herbicide treatments) with seven replications of each treatment. The main plot consisted of cultivar and replication and subplots were antitranspirant and herbicide treatments.

Plant height and the number of leaves per plant were recorded at treatment. At 2 WAT, herbicide injury ratings from 0 (no injury) to 10 (plant death) were recorded and the total length of all shoots per plant were measured to calculate the increase in shoot length from the date of treatment. The increase in the number of leaves from the date of treatment, and the number live and aborted flowers and buds were recorded at 4 WAT. The number of live reproductive organs (flower buds and flowers) were then calculated. Flowers that withered without setting a fruit were considered aborted. Throughout the study, ripe tomatoes were harvested and fresh weights were obtained. At 12 WAT, plants were harvested, roots were washed free of potting medium, and plant tissue was oven-dried at $65^{\circ} \mathrm{C}$ to determine plant dry weights. Also, the number of live reproductive organs (flower buds, flowers, ripe and unripe fruit), aborted flowers and buds, and the fresh weight of all remaining immature fruit from plants were recorded at 12 WAT.

Data were analyzed using PROC GLIMMIX in SAS (SAS Institute, Cary, NC). A rank transformation was performed on herbicide injury ratings, excluding treatments (i.e., nontreated controls) that did not exhibit injury. However, results from back-transformed injury ratings are presented because results were similar. A

Poisson distribution was used to analyze the numbers of leaves and reproductive organs. Replication and replication $\times$ cultivar were considered random effects and antitranspirant, herbicide, and all other interactions were considered fixed effects. The odds (i.e., probability) of aborted flowers as a proportion of all reproductive organs were calculated, using the GLMMIX procedure with a link $=$ logit function for a binomial distribution. Odds were calculated from the antilog of the logit value and back-transformed [\% floral abortion = odds $/$ $(1+$ odds $)]$ for reporting percent floral abortion for each cultivar/herbicide treatment combination. Means were separated using Fisher's protected least significant difference test $(P \leq 0.05)$.

Expt. 2. In early June 2019, tomato seeds were sown, and the previous experiment was repeated. However, because the TF treatments appeared less promising than the other two antitranspirants, these treatments were eliminated from this study. 'BB' and 'FL' tomato plants were dipped in ML or WP solutions on 9 July 2019, and herbicides were applied $24 \mathrm{~h}$ later. Other experimental procedures and data analyses were performed as previously described.

\section{Results}

\section{Expt. 1: Plant injury symptoms}

None of the plants treated with an antitranspirant alone exhibited any injury symptoms at 2 WAT (Table 1). Because results for antitranspirants used alone were often similar to nontreated controls, only limited reference to these treatments are made hereafter. Dicamba

Table 1. Expt. 1: 'Big Beef' and 'Florida 91' plant injury ratings at 2 WAT following antitranspirant and herbicide applications. ${ }^{\mathrm{z}}$

\begin{tabular}{lllcl}
\hline & & & Herbicide & \\
\cline { 2 - 5 } & Antitranspirant & Dicamba & $2,4-\mathrm{D}$ & None \\
\hline Cultivar & & & & \\
Big Beef & Moisture-Loc & $5.9 \mathrm{Ba}$ & $2.6 \mathrm{Cb}$ & - \\
& Wilt-Pruf & $5.8 \mathrm{Ba}$ & $3.5 \mathrm{Ba}$ & - \\
& Transfilm & $7.0 \mathrm{Aa}$ & $5.7 \mathrm{Ab}$ & - \\
& None & $6.8 \mathrm{~A}$ & $5.6 \mathrm{Ab}$ & - \\
& Moisture-Loc & $5.0 \mathrm{~B}$ & $2.8 \mathrm{Bb}$ & - \\
Florida 91 & Wilt-Pruf & $4.8 \mathrm{Ba}$ & $2.6 \mathrm{Bb}$ & - \\
& Transfilm & $6.1 \mathrm{Aa}$ & $3.8 \mathrm{Ab}$ & - \\
& None & $6.0 \mathrm{Aa}$ & $3.9 \mathrm{Ab}$ & - \\
Significant effects & & & & \\
Cultivar (C) & & & $* *$ & \\
Antitranspirant (A) & & & $* * *$ & \\
Herbicide (H) & & & $\mathrm{NS}$ & \\
$\mathrm{C} \times \mathrm{A}$ & & & $\mathrm{NS}$ & \\
$\mathrm{C} \times \mathrm{H}$ & & & $*$ & \\
$\mathrm{~A} \times \mathrm{H}$ & & & & \\
$\mathrm{C} \times \mathrm{A} \times \mathrm{H}$ & & & & \\
\hline
\end{tabular}

$\overline{{ }^{\mathrm{z}} \text { Antitranspirants were applied to tomato plants } 24 \mathrm{~h} \text { before herbicide treatments. The shoot growth of }}$ each plant was dipped in a solution of Moisture-Loc or Wilt-Pruf at $100 \mathrm{~g} \cdot \mathrm{L}^{-1}$ or Transfilm at 50 $\mathrm{g} \cdot \mathrm{L}^{-1}$ for $5 \mathrm{~s}$. Herbicides were applied at $1 / 200$ of the labeled rate (dicamba $0.56 \mathrm{~kg}$ ae/ha or 2,4-D $1.06 \mathrm{~kg}$ ae/ha). Values represent seven replications of each treatment. Visual rating scale was 0 (no plant injury) to 10 (plant mortality). WAT $=$ weeks after treatment. Means for each cultivar and herbicide treatment within a column followed by the same uppercase letters and means within a row followed by the same lowercase letters are not significantly different by Fisher's protected least significant difference test, $P \leq 0.05$.

Dash (-) indicates no plant injury observed.

Ns, ***, **, *Indicate nonsignificance or statistical significance at $P \leq 0.001,0.01$, or 0.05 , respectively. 


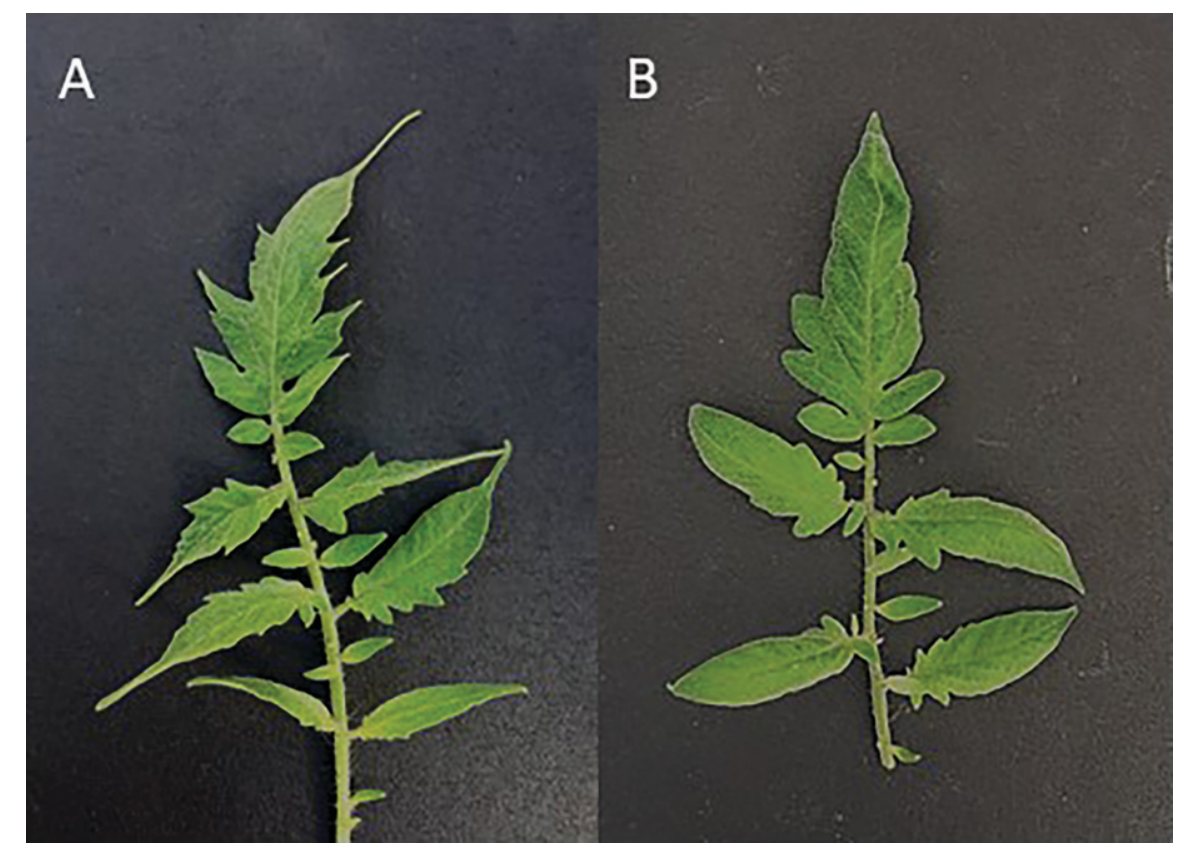

Fig. 1. (A) An elongated and distinctly acuminate leaflet on a 'Big Beef' plant treated with dicamba at $1 / 200$ the labeled rate and (B) nontreated control leaflet at 2 weeks after treatment.

alone caused reflexed foliar cupping and distortion on both tomato cultivars by 2 WAT. The terminal apices of leaflets on both cultivars treated with dicamba or 2,4-D were also more elongated and distinctly acuminate compared with nontreated control leaflets (Fig. 1). The apical portion of the main stem present at the time of treatment was swollen and stunted with an undersized leaf on both dicamba-treated cultivars by 2 WAT (Fig. 2). Both herbicides induced stem epinasty and promoted the development of adventitious root initials on the main stems of plants (Fig. 3). Tomato plants treated with 2,4-D developed swollen nodes on

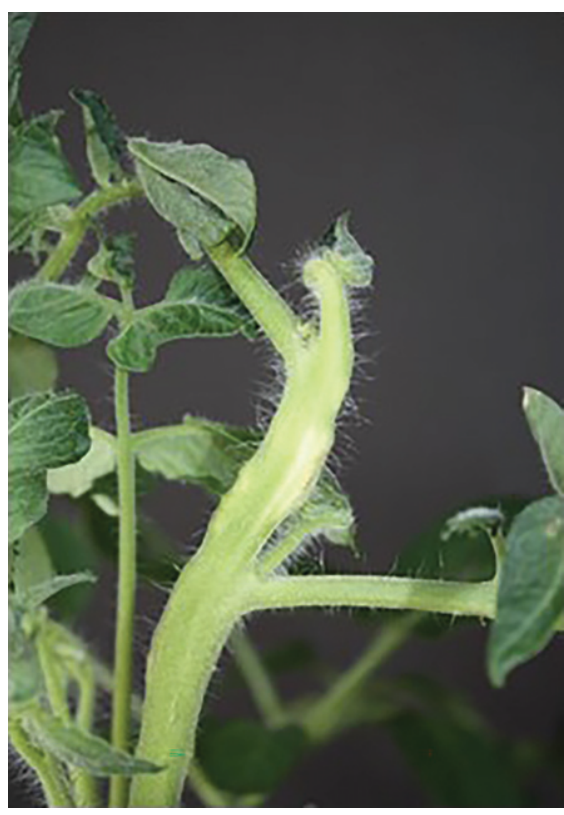

Fig. 2. Swollen and stunted main stem of a 'Florida 91' plant treated with dicamba at $1 / 200$ the labeled rate at 2 weeks after treatment. the primary stem. Twisting and malformation of leaflets were also observed on 2,4-D-treated plants of both cultivars.

There was a cultivar $x$ antitranspirant $x$ herbicide interaction for plant injury ratings (Table 1). All plants treated with an antitranspirant and an herbicide exhibited injury by 2 WAT. However, when ML or WP was used before either herbicide on 'BB' plants, injury ratings were lower than each associated herbicide used alone. Similar results were observed on 'FL' plants. For both cultivars,

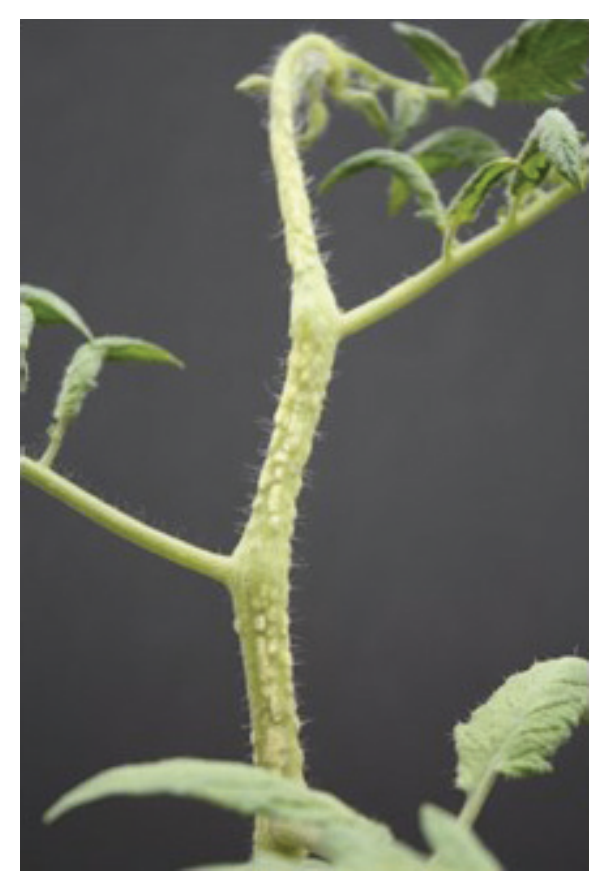

Fig. 3. Swollen nodes and adventitious root initials on a stem of a 'Big Beef' plant treated with 2,4-D at $1 / 200$ of the labeled rate at 2 weeks after treatment. injury ratings for plants treated with dicamba only were higher than those for plants treated with 2,4-D only.

Vegetative growth. All two-way interactions were significant for the increase in shoot length at 2 WAT (Table 2). The cultivar $\times$ herbicide interaction revealed that 'BB' plants treated with 2,4-D, dicamba, or nontreated controls had $36 \%, 45 \%$, or $25 \%$ more shoot elongation, respectively, than comparable treatments on 'FL' plants (data not shown). The antitranspirant $\times$ herbicide interaction was also significant for increase in shoot length. For both cultivars, shoot length was decreased by dicamba alone and increased by 2,4-D alone compared with the nontreated controls. The only antitranspirant followed by herbicide treatment combination that had less shoot growth than dicamba alone was TF followed by dicamba for both cultivars. None of the antitranspirants followed by 2,4-D treatment combinations differed in shoot length from 2,4-D alone on 'BB' and ' $\mathrm{FL}$ ' plants.

The main effect of cultivar was significant for the increase in leaf number by 4 WAT (Table 2). 'BB' plants produced more new leaves (8.4) than those of ' $F L$ ' (8.0). The interaction of antitranspirant-by-herbicide was also significant for the increase in leaf number by 4 WAT (Table 2). Plants of both cultivars treated with dicamba alone or 2,4-D alone had a $19 \%$ or $37 \%$ increase in leaf number, respectively, compared with nontreated controls. None of the antitranspirants used before dicamba suppressed the increased leaf numbers caused by dicamba alone. However, the proliferation of foliar growth associated with the application of 2,4-D alone was suppressed when 'BB' and 'FL' plants were treated with ML or WP before the 2,4-D application.

By 12 WAT, none of the plants receiving a 2,4-D treatment exhibited symptoms of injury on young distal leaflets of 'BB' plants, whereas all dicamba-treated 'BB' plants still displayed minor distortions on new leaflets. For 'FL', the only plants that had distorted distal leaflets where those pretreated with TF before 2,4-D or those sprayed with dicamba.

For plant dry weight, only the effects of cultivar and herbicide were significant by 12 WAT. 'BB' plants had greater mean dry weight $(93 \mathrm{~g})$ than ' $\mathrm{FL}$ ' plants $(58 \mathrm{~g})(P<$ $0.0001)$. Dicamba alone and 2,4-D alone reduced dry weight by $35 \%$ and $20 \%$ compared with nontreated control plants $(P<$ 0.0001 ). None of the antitranspirants mitigated the negative effect of either herbicide on plant dry weight.

Reproductive growth. The effects of cultivar, antitranspirant, and herbicide were significant for the number of live reproductive organs at $P=0.0012, P<0.0001$, and $P<0.0001$, respectively, whereas all interactions were nonsignificant by 4 WAT. The mean number of live reproductive organs for all 'BB' plants was 9.1, whereas 'FL' plants averaged 12.6 reproductive organs. Among antitranspirant treatments, plants treated with ML and WP had more live reproductive organs (12 to 13 ) than those treated with TF or nontreated controls 
Table 2. Expt. 1: Increase in shoot length at 2 WAT and increase in leaf number at 4 WAT after antitranspirant and herbicide applications on 'Big Beef' and 'Florida 91' tomato plants. ${ }^{\mathrm{A}}$

\begin{tabular}{|c|c|c|c|c|c|c|}
\hline & \multicolumn{3}{|c|}{ Shoot length $(\mathrm{cm})$} & \multicolumn{3}{|c|}{ Leaf no. } \\
\hline & \multicolumn{3}{|c|}{ Herbicide } & \multicolumn{3}{|c|}{ Herbicide } \\
\hline & Dicamba & 2,4-D & None & Dicamba & 2,4-D & None \\
\hline \multicolumn{7}{|l|}{ Antitranspirant } \\
\hline Moisture-Loc & $23.9 \mathrm{Ab}$ & $46.6 \mathrm{Ba}$ & $43.8 \mathrm{Aa}$ & $27.0 \mathrm{Aa}$ & $24.2 \mathrm{Ba}$ & $17.7 \mathrm{Ab}$ \\
\hline Wilt-Pruf & $24.5 \mathrm{Ac}$ & $51.0 \mathrm{Aa}$ & $42.4 \mathrm{ABb}$ & $29.4 \mathrm{Aa}$ & $24.5 \mathrm{Bb}$ & $19.2 \mathrm{Ac}$ \\
\hline Transfilm & $17.7 \mathrm{Bc}$ & $49.4 \mathrm{ABa}$ & $40.0 \mathrm{Bb}$ & $26.5 \mathrm{Aa}$ & $27.6 \mathrm{ABa}$ & $17.4 \mathrm{Ab}$ \\
\hline None & $24.6 \mathrm{Ac}$ & $48.7 \mathrm{ABa}$ & $36.7 \mathrm{Cb}$ & $23.6 \mathrm{Bb}$ & $30.2 \mathrm{Aa}$ & $19.0 \mathrm{Ac}$ \\
\hline \multicolumn{7}{|l|}{ Significant effects } \\
\hline Cultivar (C) & & $* * *$ & & & ** & \\
\hline Antitranspirant (A) & & * & & & NS & \\
\hline Herbicide $(\mathrm{H})$ & & $* * *$ & & & $* * *$ & \\
\hline $\mathrm{C} \times \mathrm{A}$ & & * & & & NS & \\
\hline $\mathrm{C} \times \mathrm{H}$ & & ** & & & NS & \\
\hline $\mathrm{A} \times \mathrm{H}$ & & ** & & & ** & \\
\hline $\mathrm{C} \times \mathrm{A} \times \mathrm{H}$ & & NS & & & NS & \\
\hline
\end{tabular}

${ }^{\mathrm{z}}$ Antitranspirants were applied to tomato plants $24 \mathrm{~h}$ before herbicide treatments. The shoot growth of each plant was dipped in a solution of Moisture-Loc or Wilt-Pruf at $100 \mathrm{~g} \cdot \mathrm{L}^{-1}$ or Transfilm at $50 \mathrm{~g} \cdot \mathrm{L}^{-1}$ for $5 \mathrm{~s}$. Herbicides were applied at $1 / 200$ of the labeled rate (dicamba $0.56 \mathrm{~kg}$ ae/ha or 2,4-D $1.06 \mathrm{kgae} / \mathrm{ha}$ ). Values represent seven replications of each treatment. WAT $=$ weeks after treatment. Means within a column followed by the same uppercase letters and means within a row followed by the same lowercase letters are not significantly different by Fisher's protected least significant difference test, $P \leq 0.05$.

Ns, ***, **, *Indicate nonsignificance or statistical significance at $P \leq 0.001,0.01$, or 0.05 , respectively.

(9). For all herbicide treatments, nontreated and 2,4-D-treated plants had $41 \%$ and $47 \%$ more live reproductive organs, respectively, than dicamba-treated plants.

By 12 WAT, all two-way interactions for the number of live reproductive organs were significant (Table 3 ). The cultivar $\times$ herbicide interaction revealed that ' $\mathrm{BB}$ ' plants treated with 2,4-D, dicamba, or nontreated controls had $52 \%, 60 \%$, or $36 \%$ more live reproductive organs, respectively, than comparable treatments on 'FL' plants (data not shown). The antitranspirant $\times$ herbicide interaction revealed that either herbicide applied alone reduced the with the nontreated controls by nearly $50 \%$ (Table 3). However, plants treated with any antitranspirant before dicamba had more live reproductive organs than those treated with dicamba alone. Similar results were obtained when an antitranspirant was used before 2,4-D compared with 2,4-D alone.

The cultivar $\times$ herbicide interaction was significant for flower abortion by 4 WAT and 12 WAT (Table 3 ). The cultivar $\times$ herbicide interaction revealed that ' $\mathrm{BB}$ ' plants treated with $2,4-\mathrm{D}$, dicamba, or nontreated controls had $41 \%, 46 \%$, or $45 \%$ number of live reproductive organs compared more aborted flowers, respectively, than comparable treatments on 'FL' plants by 12 WAT (data not shown). The interaction of antitranspirant-by-herbicide was also significant for flower abortion by 4 WAT and 12 WAT. Plants of both cultivars treated with dicamba alone had greater percentages of flower abortion than those treated with 2,4-D alone at both evaluation dates. The negative effect of dicamba alone on flower abortion was mitigated by the application of ML or WP before dicamba treatment. The adverse effect of 2,4-D alone was reduced when ML, TF, or WP was applied before the application of 2,4-D.

The three-way interaction was significant for total fruit weight by 12 WAT (Table 4). Nontreated control plants and those treated with 2,4-D alone produced similar total fruit weights for both cultivars. However, the application of dicamba alone reduced total fruit weight of 'BB' and 'FL' by 91 and $58 \%$, respectively, compared with nontreated controls. 'BB' plants treated with TF before the application of either herbicide produced only small immature fruit during the experimental period. Also, none of the plants pretreated with ML or WP before either herbicide produced greater total fruit weight than dicamba or 2,4-D alone. However, 'FL' plants treated with WP before 2,4-D had more fruit weight than plants treated with 2,4-D alone.

\section{Expt. 2: Plant injury symptoms}

The interaction of antitranspirant $x$ herbicide was significant for injury ratings by 2 WAT, but the three-way interaction was not significant (Table 5). Plants of both cultivars treated with dicamba alone exhibited more injury than those treated

Table 3. Expt. 1: Number of reproductive organs at $12 \mathrm{WAT}$ and percent flower abortion at 4 and $12 \mathrm{WAT}$ following antitranspirant and herbicide applications on 'Big Beef' and 'Florida 91' tomato plants. ${ }^{\mathrm{Z}}$

\begin{tabular}{|c|c|c|c|c|c|c|c|c|c|}
\hline & \multicolumn{3}{|c|}{ No. of live reproductive organs } & \multicolumn{3}{|c|}{ Aborted flowers at 4 WAT $(\%)^{\mathrm{y}}$} & \multicolumn{3}{|c|}{ Aborted flowers at 12 WAT $(\%)^{\mathrm{y}}$} \\
\hline & \multicolumn{3}{|c|}{ Herbicide } & \multicolumn{3}{|c|}{ Herbicide } & \multicolumn{3}{|c|}{ Herbicide } \\
\hline & Dicamba & $2,4-\mathrm{D}$ & None & Dicamba & $2,4-\mathrm{D}$ & None & Dicamba & $2,4-\mathrm{D}$ & None \\
\hline Moisture-Loc & $34.6 \mathrm{ABc}$ & $44.2 \mathrm{Ab}$ & $56.0 \mathrm{Aa}$ & $30.8 \mathrm{Ba}$ & $23.8 \mathrm{BCb}$ & $17.7 \mathrm{Bb}$ & $50.3 \mathrm{Ca}$ & $45.8 \mathrm{Cb}$ & $38.4 \mathrm{Bc}$ \\
\hline Wilt-Pruf & $37.5 \mathrm{Ab}$ & $43.2 \mathrm{Aa}$ & $46.0 \mathrm{Ba}$ & $31.0 \mathrm{Ba}$ & $21.8 \mathrm{Cb}$ & $15.7 \mathrm{Bb}$ & $53.1 \mathrm{BCa}$ & $48.2 \mathrm{BCb}$ & $40.9 \mathrm{ABc}$ \\
\hline Transfilm & $34.0 \mathrm{Bc}$ & $39.0 \mathrm{Ab}$ & $44.9 \mathrm{Ba}$ & $53.1 \mathrm{Aa}$ & $29.3 \mathrm{Bb}$ & $26.3 \mathrm{Ab}$ & $57.0 \mathrm{Ba}$ & $51.3 \mathrm{Bb}$ & 43.9 Ac \\
\hline None & $27.0 \mathrm{Cb}$ & $29.8 \mathrm{Bb}$ & $57.1 \mathrm{Aa}$ & $53.5 \mathrm{Aa}$ & $37.1 \mathrm{Ab}$ & $14.5 \mathrm{Bc}$ & $71.3 \mathrm{Aa}$ & $66.1 \mathrm{Ab}$ & $28.4 \mathrm{Cc}$ \\
\hline Antitranspirant (A) & & $* * *$ & & & $* * *$ & & & ** & \\
\hline Herbicide $(\mathrm{H})$ & & $* * *$ & & & $* * *$ & & & $* * *$ & \\
\hline $\mathrm{C} \times \mathrm{A}$ & & $* * *$ & & & $* *$ & & & $* * *$ & \\
\hline $\mathrm{C} \times \mathrm{H}$ & & $* * *$ & & & $*$ & & & $* * *$ & \\
\hline $\mathrm{A} \times \mathrm{H}$ & & $* * *$ & & & * & & & $* * *$ & \\
\hline $\mathrm{C} \times \mathrm{A} \times \mathrm{H}$ & & NS & & & NS & & & NS & \\
\hline
\end{tabular}

${ }^{\mathrm{z}}$ Antitranspirants were applied to tomato plants $24 \mathrm{~h}$ before herbicide treatments. The shoot growth of each plant was dipped in a solution of MoistureLoc or Wilt-Pruf at $100 \mathrm{~g} \cdot \mathrm{L}^{-1}$ or Transfilm at $50 \mathrm{~g} \cdot \mathrm{L}^{-1}$ for $5 \mathrm{~s}$. Herbicides were applied at $1 / 200$ of the labeled rate (dicamba $0.56 \mathrm{~kg}$ ae/ha or $2,4-\mathrm{D} 1.06$ $\mathrm{kg}$ ae/ha). Live reproductive organs include flower buds, flowers, and ripe and unripe fruit. Values represent seven replications of each treatment. WAT $=$ weeks after treatment. Means within a column followed by the same uppercase letters and means within a row followed by the same lowercase letters are not significantly different by Fisher's protected least significant difference test, $P \leq 0.05$.

${ }^{\mathrm{y}}$ PROC GLIMMIX using a link = logit function for binomial distributions was used to analyze floral abortion data as proportion of the total number of reproductive organs. Back transformed data $[\%$ flower abortion $=$ odds $/(1+$ odds $)]$ are presented.

Ns, ***,**, *Indicate nonsignificance or statistical significance at $P \leq 0.001,0.01$, or 0.05 , respectively. 
Table 4. Expt. 1: Total fruit weight in grams of 'Big Beef' and 'Florida 91' at 12 WAT following antitranspirant and herbicide applications. ${ }^{\mathrm{z}}$

\begin{tabular}{|c|c|c|c|c|}
\hline & \multirow[b]{3}{*}{ Antitranspirant } & \multicolumn{3}{|c|}{ Herbicide } \\
\hline & & Dicamba & 2,4-D & None \\
\hline & & & (g) & \\
\hline \multicolumn{5}{|l|}{ Cultivar } \\
\hline \multirow[t]{4}{*}{ Big Beef } & Moisture-Loc & $41.5 \mathrm{Aa}$ & $29.8 \mathrm{Aa}$ & $34.5 \mathrm{Ca}$ \\
\hline & Wilt-Pruf & $18.5 \mathrm{Aa}$ & $63.0 \mathrm{Aa}$ & $70.5 \mathrm{BCa}$ \\
\hline & Transfilm & $2.2 \mathrm{Ab}$ & $3.3 \mathrm{Ab}$ & $162.2 \mathrm{Aa}$ \\
\hline & None & $11.8 \mathrm{Ab}$ & $70.0 \mathrm{Aab}$ & 126.6 Aa \\
\hline \multirow[t]{4}{*}{ Florida 91} & Moisture-Loc & $63.0 \mathrm{Ab}$ & 118.6 Bab & $190.0 \mathrm{Ba}$ \\
\hline & Wilt-Pruf & $58.8 \mathrm{Ab}$ & $233.5 \mathrm{Aa}$ & $287.4 \mathrm{Aa}$ \\
\hline & Transfilm & $122.1 \mathrm{Ab}$ & $122.7 \mathrm{Bb}$ & $203.0 \mathrm{Ba}$ \\
\hline & None & $78.3 \mathrm{Ab}$ & $160.3 \mathrm{Ba}$ & $186.7 \mathrm{Ba}$ \\
\hline \multicolumn{5}{|l|}{ Significant effects } \\
\hline Cultivar (C) & & & $* * *$ & \\
\hline Antitranspirant (A) & & & NS & \\
\hline Herbicide $(\mathrm{H})$ & & & $* * *$ & \\
\hline $\mathrm{C} \times \mathrm{A}$ & & & NS & \\
\hline $\mathrm{C} \times \mathrm{H}$ & & & NS & \\
\hline $\mathrm{A} \times \mathrm{H}$ & & & $*$ & \\
\hline $\mathrm{C} \times \mathrm{A} \times \mathrm{H}$ & & & $*$ & \\
\hline
\end{tabular}

${ }^{\mathrm{z}}$ Antitranspirants were applied to tomato plants $24 \mathrm{~h}$ before herbicide treatments. The shoot growth of each plant was dipped in a solution of Moisture-Loc or WP at $100 \mathrm{~g} \cdot \mathrm{L}^{-1}$ or Transfilm at $50 \mathrm{~g} \cdot \mathrm{L}^{-1}$ for $5 \mathrm{~s}$ Herbicides were applied at $1 / 200$ of the labeled rate (dicamba $0.56 \mathrm{~kg}$ ae/ha or 2,4-D $1.06 \mathrm{~kg}$ ae/ha). Values represent 7 replications of each treatment. WAT $=$ weeks after treatment. Means for each cultivar and herbicide treatment within a column followed by the same uppercase letters and means within a row followed by the same lowercase letters are not significantly different by Fisher's protected least significant difference test, $P \leq 0.05$.

Ns, ${ }^{* *}, *$ Indicate nonsignificance or statistical significance at $P \leq 0.001$ or 0.05 , respectively.

with 2,4-D alone. Also, plants with either antitranspirant applied before dicamba had lower injury ratings than plants treated

Table 5. Expt. 2: 'Big Beef' and 'Florida 91' plant injury ratings at 2 WAT following antitranspirant and herbicide applications. ${ }^{\mathrm{z}}$

\begin{tabular}{|c|c|c|c|}
\hline & \multicolumn{3}{|c|}{ Visual ratings of injury } \\
\hline & \multicolumn{3}{|c|}{ Herbicide } \\
\hline & Dicamba & $2,4-\mathrm{D}$ & None \\
\hline \multicolumn{4}{|l|}{ Antitranspirant } \\
\hline Moisture-Loc & $3.7 \mathrm{Ba}$ & $3.6 \mathrm{Ba}$ & - \\
\hline Wilt-Pruf & $3.8 \mathrm{Ba}$ & $3.5 \mathrm{Ba}$ & - \\
\hline None & $6.8 \mathrm{Ba}$ & $4.9 \mathrm{Ba}$ & - \\
\hline \multicolumn{4}{|l|}{ Significant effects } \\
\hline Cultivar (C) & & NS & \\
\hline Antitranspirant (A) & & $* * *$ & \\
\hline Herbicide (H) & & $* * *$ & \\
\hline $\mathrm{C} \times \mathrm{A}$ & & NS & \\
\hline $\mathrm{C} \times \mathrm{H}$ & & NS & \\
\hline $\mathrm{A} \times \mathrm{H}$ & & $* * *$ & \\
\hline $\mathrm{C} \times \mathrm{A} \times \mathrm{H}$ & & NS & \\
\hline
\end{tabular}

${ }^{\mathrm{z}}$ Antitranspirants were applied to tomato plants $24 \mathrm{~h}$ before herbicide treatments. The shoot growth of each plant was dipped in a solution of Moisture-Loc or Wilt-Pruf at $100 \mathrm{~g} \cdot \mathrm{L}^{-1}$ or Transfilm at $50 \mathrm{~g} \cdot \mathrm{L}^{-1}$ for $5 \mathrm{~s}$. Herbicides were applied at $1 / 200$ of the labeled rate (dicamba $0.56 \mathrm{~kg}$ ae/ha or 2,4-D $1.06 \mathrm{~kg}$ ae/ha). Values represent seven replications of each treatment. WAT = weeks after treatment; NI $=$ no injury. Means within a column followed by the same uppercase letters and means within a row followed by the same lowercase letters are not significantly different by Fisher's protected least significant difference test, $P \leq 0.05$.

Dash (-) indicates no plant injury observed. Ns, *** Indicate nonsignificance or statistical significance at $P \leq 0.001$, respectively.
ML before 2,4-D had greater dry weight than those treated with 2,4-D alone.

Reproductive growth. By 4 WAT, plants treated with dicamba alone developed fewer live reproductive organs than the nontreated controls of both cultivars (Table 9). Antitranspirants applied alone reduced the number of live reproductive organs compared with the nontreated controls for both cultivars and did not mitigate herbicide injury by 4 WAT. However, plants treated with ML or WP before either herbicide developed more live reproductive organs than those treated with dicamba or 2,4-D alone by 12 WAT (Table 9).

The three-way interaction for aborted flowers was significant at 4 WAT (Table 10). For 'BB', plants treated with dicamba alone had higher percentages of flower abortion than nontreated controls. However, ML or WP applied before dicamba reduced 'BB' flower abortion by $49 \%$ or $47 \%$, respectively, compared with dicamba alone. Antitranspirants had no effect on flower abortion caused by dicamba alone on 'FL' plants. For both cultivars, percentages of flower abortion were increased by 2,4-D alone compared with the nontreated control plants. For 'FL' plants only, ML or WP mitigated the effect of 2,4-D alone on flower abortion.

Only the effects of antitranspirant $(P=$ $0.0001)$ and herbicide $(P=0.0003)$ were significant for flower abortion by 12 WAT. Across all treatments, plants treated with ML or WP antitranspirant had less flower abortion (38\% and $40 \%$, respectively) than plants not treated with an antitranspirant (52\%). Also, dicamba- or 2,4-D-treated plants had more flower abortion ( $52 \%$ and $50 \%$, respectively) than non-herbicide-treated plants (29\%).

For total fruit weight, only the effects of cultivar $(P=0.0084)$ and herbicide $(P<$ $0.0001)$ were significant at 12 WAT. 'FL' plants averaged $386 \mathrm{~g}$ total fruit weight while 'BB' averaged only 296 g. Plants treated with 2,4-D had greater total fruit weight (413 g) than nontreated plants $(309 \mathrm{~g})$ and those treated with dicamba $(280 \mathrm{~g})$.

\section{Discussion}

'FL' plants stimulated foliar growth when compared with the nontreated controls by 4 WAT (Table 7). Neither antitranspirant used before dicamba suppressed the increased foliar growth caused by dicamba. However, plants treated with ML or WP before 2,4-D had fewer leaves than those sprayed with 2,4-D only.

By 12 WAT, herbicide injury symptoms on young distal leaflets of all 'BB' plants were not apparent (data not shown). Injury symptoms on young leaflets were only visible on 'FL' plants treated with an antitranspirant before dicamba or dicamba alone.

For plant dry weight, the interaction of antitranspirant-by-herbicide was significant at 12 WAT (Table 8). The antitranspirant-by-herbicide interaction revealed that herbicides applied alone reduced plant dry weights by $33 \%$ compared with nontreated controls. However, plants treated with WP before dicamba had greater dry weight than those sprayed with dicamba alone. In contrast, plants treated with 
Table 6. Expt. 2: Increase in shoot length at 2 WAT following antitranspirant and herbicide applications on 'Big Beef' and 'Florida 91' tomato plants.

\begin{tabular}{|c|c|c|c|c|}
\hline & \multirow[b]{3}{*}{ Antitranspirant } & \multicolumn{3}{|c|}{ Shoot length $(\mathrm{cm})$} \\
\hline & & \multicolumn{3}{|c|}{ Herbicide } \\
\hline & & Dicamba & 2,4-D & None \\
\hline \multicolumn{5}{|l|}{ Cultivar } \\
\hline \multirow{3}{*}{ Big Beef } & Moisture-Loc & $56 \mathrm{ABb}$ & $77 \mathrm{Aa}$ & 65 Aab \\
\hline & Wilt-Pruf & $40 \mathrm{Bb}$ & $79 \mathrm{Aa}$ & $35 \mathrm{Bb}$ \\
\hline & None & $69 \mathrm{Aa}$ & $83 \mathrm{Aa}$ & $49 \mathrm{ABb}$ \\
\hline \multirow[t]{3}{*}{ Florida 91} & Moisture-Loc & $11 \mathrm{Ab}$ & $34 \mathrm{Ba}$ & $26 \mathrm{Aab}$ \\
\hline & Wilt-Pruf & $18 \mathrm{Aa}$ & $32 \mathrm{Ba}$ & $20 \mathrm{Aa}$ \\
\hline & None & $18 \mathrm{Ac}$ & $61 \mathrm{Aa}$ & $35 \mathrm{Ab}$ \\
\hline \multicolumn{5}{|l|}{ Significant effects } \\
\hline Cultivar (C) & & & $* *$ & \\
\hline Antitranspirant (A) & & & ** & \\
\hline Herbicide (H) & & & $* * *$ & \\
\hline $\mathrm{C} \times \mathrm{A}$ & & & NS & \\
\hline $\mathrm{C} \times \mathrm{H}$ & & & * & \\
\hline $\mathrm{A} \times \mathrm{H}$ & & & NS & \\
\hline $\mathrm{C} \times \mathrm{A} \times \mathrm{H}$ & & & * & \\
\hline
\end{tabular}

${ }^{\mathrm{z}}$ Antitranspirants were applied to tomato plants $24 \mathrm{~h}$ before herbicide treatments. The shoot growth of each plant was dipped in a solution of Moisture-Loc or Wilt-Pruf at $100 \mathrm{~g} \cdot \mathrm{L}^{-1}$ or Transfilm at 50 $\mathrm{g} \cdot \mathrm{L}^{-1}$ for $5 \mathrm{~s}$. Herbicides were applied at $1 / 200$ of the labeled rate (dicamba $0.56 \mathrm{~kg}$ ae/ha or 2,4-D $1.06 \mathrm{~kg}$ ae/ha). Values represent seven replications of each treatment. WAT $=$ weeks after treatment Means for each cultivar and herbicide treatment within a column followed by the same uppercase letters and means within a row followed by the same lowercase letters are not significantly different by Fisher's protected least significant difference test, $P \leq 0.05$.

NS, ***, **, *Indicate nonsignificance or statistical significance at $P \leq 0.001,0.01$, or 0.05 , respectively.

pronounced on 'BB', likely due to its vigorous semideterminate growth habit.

Both herbicides caused stem epinasty in our experiments, which has been widely

Table 7. Expt. 2: Increase in leaf number at 4 WAT following antitranspirant and herbicide applications on 'Big Beef' and 'Florida 91' tomato plants. ${ }^{\text {Z }}$

\begin{tabular}{lccc}
\hline & \multicolumn{3}{c}{ Leaf no. } \\
\cline { 2 - 4 } & \multicolumn{3}{c}{ Herbicide } \\
\cline { 2 - 4 } & Dicamba & $2,4-\mathrm{D}$ & None \\
\hline Antitranspirant & & & \\
Moisture-Loc & $31.9 \mathrm{Aa}$ & $27.8 \mathrm{Ba}$ & $18.9 \mathrm{Ab}$ \\
Wilt-Pruf & $34.8 \mathrm{Aa}$ & $27.5 \mathrm{Bb}$ & $18.5 \mathrm{Ac}$ \\
None & $28.3 \mathrm{Aa}$ & $34.6 \mathrm{Aa}$ & $20.6 \mathrm{Ab}$ \\
Significant effects & & & \\
Cultivar (C) & & $\mathrm{NS}$ & \\
Antitranspirant & & $\mathrm{NS}$ & \\
$\quad(\mathrm{A})$ & & $* * *$ \\
Herbicide (H) & & $\mathrm{NS}$ \\
$\mathrm{C} \times \mathrm{A}$ & & $* *$ \\
$\mathrm{C} \times \mathrm{H}$ & & $*$ \\
$\mathrm{~A} \times \mathrm{H}$ & & $\mathrm{NS}$ \\
$\mathrm{C} \times \mathrm{A} \times \mathrm{H}$ & & & \\
\end{tabular}

${ }^{\mathrm{z}}$ Antitranspirants were applied to tomato plants $24 \mathrm{~h}$ before herbicide treatments. The shoot growth of each plant was dipped in a solution of Moisture-Loc or Wilt-Pruf at $100 \mathrm{~g} \cdot \mathrm{L}^{-1}$ or Transfilm at $50 \mathrm{~g} \cdot \mathrm{L}^{-1}$ for 5 s. Herbicides were applied at $1 / 200$ of the labeled rate (dicamba $0.56 \mathrm{~kg}$ ae/ha or 2,4-D $1.06 \mathrm{~kg}$ ae/ha). Values represent seven replications of each treatment. $\mathrm{WAT}=$ weeks after treatment. Means within a column followed by the same uppercase letters and means within a row followed by the same lowercase letters are not significantly different by Fisher's protected least significant difference test, $P \leq 0.05$.

NS, $* * * * *, *$ Indicate nonsignificance or statistical significance at $P \leq 0.001,0.01$, or 0.05 , respectively. develop into adventitious roots capable of breaking through the epidermis (Guan et al., tomato stems after wounding. In the tomato pericycle, wounding induces auxin transporters, resulting in auxin accumulation in founder cell initiation sites that differentiate and 'Big Beef' and 'Florida 91' tomato plants.
2019). This wound response may therefore parallel the response to low dose auxin-type herbicides by inducing expression of genes that ultimately result in the development of root initials.

In both experiments, the appearance of new, undamaged terminal leaflets on the main stems indicated that 2,4-D-treated plants began to recover vegetatively from injury by 12 WAT.

Also, total fruit weight of 'FL' plants treated with 2,4-D alone was greater than those treated with dicamba alone in Expt. 1 (Table 4) and both cultivars in Expt. 2 by 12 WAT. Collectively, these results indicate that tomato plants may recover more rapidly from 2,4-D injury than from dicamba injury. Peterson et al. (2016) also reported that some plant species recover from exposure to low rates of auxin herbicides.

Overall, little fruit matured on plants during the 12-week experimental periods. However, 'FL' plants produced more total fruit weight than those of 'BB'. The cultivar difference in fruit weight is likely due to the productivity of ' $\mathrm{FL}$ ' and its tendency to set tomatoes at warm temperatures (Koske et al., 2009).

The mitigation of dicamba and 2,4-D injury to tomato plants also varied among the film-forming antitranspirants. In the first experiment, TF provided no early protection against herbicide injury and its efficacy was inconsistent at 12 WAT (Tables 1 and 3). In contrast, the application of either ML or WP before an herbicide application partially mitigated plant injury symptoms at 2 WAT and resulted in more live reproductive organs when compared with the respective herbicide treatment alone at 12 WAT (Tables 1, 3, and 9). In other studies, auxin-type herbicides stimulated cell elongation of plants within an hour of treatment and enhanced the accumulation of potassium ions in guard cells, resulting in larger stomatal aperture size for 5

to $16 \mathrm{~h}$ and photosynthesis for 5 to $20 \mathrm{~h}$ after

Table 8. Expt. 2: Plant dry weight at 12 WAT following antitranspirant and herbicide applications on

\begin{tabular}{|c|c|c|c|}
\hline & \multicolumn{3}{|c|}{$\begin{array}{c}\text { Plant dry weight (g) } \\
\text { Herbicide }\end{array}$} \\
\hline & Dicamba & $2,4-\mathrm{D}$ & None \\
\hline \multicolumn{4}{|l|}{ Antitranspirant } \\
\hline Moisture-Loc & $67.3 \mathrm{ABa}$ & $76.9 \mathrm{Aa}$ & $60.3 \mathrm{ABa}$ \\
\hline Wilt-Pruf & $79.1 \mathrm{Aa}$ & $65.4 \mathrm{ABab}$ & $54.4 \mathrm{Bb}$ \\
\hline None & $52.3 \mathrm{Bb}$ & $52.4 \mathrm{Bb}$ & $78.0 \mathrm{Aa}$ \\
\hline \multicolumn{4}{|l|}{ Significant effects } \\
\hline Cultivar (C) & & ** & \\
\hline Antitranspirant (A) & & NS & \\
\hline Herbicide $(\mathrm{H})$ & & NS & \\
\hline $\mathrm{C} \times \mathrm{A}$ & & NS & \\
\hline $\mathrm{C} \times \mathrm{H}$ & & NS & \\
\hline $\mathrm{A} \times \mathrm{H}$ & & $* * *$ & \\
\hline $\mathrm{C} \times \mathrm{A} \times \mathrm{H}$ & & NS & \\
\hline
\end{tabular}

${ }^{\mathrm{z}}$ Antitranspirants were applied to tomato plants $24 \mathrm{~h}$ before herbicide treatments. The shoot growth of each plant was dipped in a solution of Moisture-Loc or Wilt-Pruf at $100 \mathrm{~g} \cdot \mathrm{L}^{-1}$ or Transfilm at $50 \mathrm{~g} \cdot \mathrm{L}^{-1}$ for $5 \mathrm{~s}$. Herbicides were applied at $1 / 200$ of the labeled rate (dicamba $0.56 \mathrm{~kg}$ ae/ha or 2,4-D $1.06 \mathrm{~kg}$ ae/ ha). Values represent seven replications of each treatment. WAT $=$ weeks after treatment. Means within a column followed by the same uppercase letters and means within a row followed by the same lowercase letters are not significantly different by Fisher's protected least significant difference test, $P \leq 0.05$. Ns, ***, **Indicate nonsignificance or statistical significance at $P \leq 0.001$ or 0.01 , respectively. 
Table 9. Expt. 2: The number of live reproductive organs at 4 and 12 WAT following antitranspirant and herbicide applications on 'Big Beef' and 'Florida 91' tomato plants.

\begin{tabular}{|c|c|c|c|c|c|c|}
\hline & \multicolumn{3}{|c|}{ No. live repro. organs at $4 \mathrm{WAT}$} & \multicolumn{3}{|c|}{ No. live repro. organs at 12 WAT } \\
\hline & \multicolumn{3}{|c|}{ Herbicide } & \multicolumn{3}{|c|}{ Herbicide } \\
\hline & Dicamba & 2,4-D & None & Dicamba & 2,4-D & None \\
\hline \multicolumn{7}{|l|}{ Antitranspirant } \\
\hline Moisture-Loc & $9.8 \mathrm{Ab}$ & $14.0 \mathrm{Aba}$ & $11.0 \mathrm{Bab}$ & $37.4 \mathrm{Aa}$ & $34.9 \mathrm{Aa}$ & $37.3 \mathrm{Aa}$ \\
\hline Wilt-Pruf & $9.8 \mathrm{Ab}$ & $15.0 \mathrm{Aa}$ & $10.4 \mathrm{Bb}$ & $35.9 \mathrm{Aab}$ & $31.3 \mathrm{Ab}$ & $36.8 \mathrm{Aa}$ \\
\hline None & $9.8 \mathrm{Ab}$ & $12.5 \mathrm{Bab}$ & $14.3 \mathrm{Aa}$ & $20.9 \mathrm{Bb}$ & $22.3 \mathrm{Bb}$ & $41.8 \mathrm{Aa}$ \\
\hline \multicolumn{7}{|l|}{ Significant effects } \\
\hline Cultivar (C) & & * & & & ** & \\
\hline Antitranspirant (A) & & NS & & & $* * *$ & \\
\hline Herbicide $(\mathrm{H})$ & & $* *$ & & & $* * *$ & \\
\hline $\mathrm{C} \times \mathrm{A}$ & & NS & & & NS & \\
\hline $\mathrm{C} \times \mathrm{H}$ & & NS & & & NS & \\
\hline $\mathrm{A} \times \mathrm{H}$ & & $*$ & & & $* * *$ & \\
\hline $\mathrm{C} \times \mathrm{A} \times \mathrm{H}$ & & NS & & & NS & \\
\hline
\end{tabular}

${ }^{\mathrm{z}}$ Antitranspirants were applied to tomato plants $24 \mathrm{~h}$ before herbicide treatments. The shoot growth of each plant was dipped in a solution of Moisture-Loc or Wilt-Pruf at $100 \mathrm{~g} \cdot \mathrm{L}^{-1}$ or Transfilm at 50 $\mathrm{g} \cdot \mathrm{L}^{-1}$ for $5 \mathrm{~s}$. Herbicides were applied at $1 / 200$ of the labeled rate (dicamba $0.56 \mathrm{~kg}$ ae/ha or 2,4-D $1.06 \mathrm{~kg}$ ae/ha). Live reproductive organs include flower buds, flowers, and ripe and unripe fruit. Values represent seven replications of each treatment. WAT = weeks after treatment. Means within a column followed by the same uppercase letters and means within a row followed by the same lowercase letters are not significantly different by Fisher's protected least significant difference test, $P \leq 0.05$. Ns, ***, **, *Indicate nonsignificance or statistical significance at $P \leq 0.001,0.01$, or 0.05 , respectively.

treatment (Cobb, 1992; Thompson, 1989). Thus, thorough coverage of enlarged stomatal apertures on leaf surfaces with an antitranspirant at a sufficient rate may be necessary to adequately mitigate plant injury caused by an auxin-type herbicide. Albrigo (1972) showed that a 3\% spray of pinolene antitranspirant (i.e., WP) partially, but not completely, covered stomatal

openings. In a preliminary experiment, $2 \%$ or $3 \%$ solutions of ML or WP alone did not cause phytotoxicity (M.R. Warmund, unpublished data). However, a $1 \%$ solution of ML or WP was selected for this study, using the manufacturer's labeled rate. Although not examined in the current study, incomplete stomatal coverage or slight breaks in the film layer may have

Table 10. Expt. 2: Percent of aborted flowers at 4 WAT following antitranspirant and herbicide applications on 'Big Beef' and 'Florida 91' tomato plants. ${ }^{\mathrm{z}}$

\begin{tabular}{|c|c|c|c|c|}
\hline & \multirow[b]{3}{*}{ Antitranspirant } & \multicolumn{3}{|c|}{ Aborted flowers $(\%)^{\mathrm{y}}$} \\
\hline & & \multicolumn{3}{|c|}{ Herbicide } \\
\hline & & Dicamba & $2,4-\mathrm{D}$ & None \\
\hline \multicolumn{5}{|l|}{ Cultivar } \\
\hline \multirow[t]{3}{*}{ Big Beef } & Moisture-Loc & $20.8 \mathrm{Ba}$ & $20.5 \mathrm{Aa}$ & $17.0 \mathrm{Aa}$ \\
\hline & Wilt-Pruf & $21.5 \mathrm{Ba}$ & $20.2 \mathrm{Aa}$ & $15.5 \mathrm{Aa}$ \\
\hline & None & $40.8 \mathrm{Aa}$ & $30.1 \mathrm{Aa}$ & $7.0 \mathrm{Ab}$ \\
\hline \multirow[t]{3}{*}{ Florida 91} & Moisture-Loc & $25.6 \mathrm{Aa}$ & $11.5 \mathrm{Bb}$ & $16.8 \mathrm{Aab}$ \\
\hline & Wilt-Pruf & $30.0 \mathrm{Aa}$ & $16.6 \mathrm{Bb}$ & $13.2 \mathrm{Ab}$ \\
\hline & None & $21.9 \mathrm{Aa}$ & $26.8 \mathrm{Aa}$ & $13.1 \mathrm{Ab}$ \\
\hline \multicolumn{5}{|l|}{ Significant effects } \\
\hline Cultivar (C) & & & NS & \\
\hline Antitranspirant (A) & & & NS & \\
\hline Herbicide $(\mathrm{H})$ & & & $* * *$ & \\
\hline $\mathrm{C} \times \mathrm{A}$ & & & NS & \\
\hline $\mathrm{C} \times \mathrm{H}$ & & & NS & \\
\hline $\mathrm{A} \times \mathrm{H}$ & & & $*$ & \\
\hline $\mathrm{C} \times \mathrm{A} \times \mathrm{H}$ & & & $*$ & \\
\hline
\end{tabular}

${ }^{\mathrm{z}}$ Antitranspirants were applied to tomato plants $24 \mathrm{~h}$ before herbicide treatments. The shoot growth of each plant was dipped in a solution of Moisture-Loc or Wilt-Pruf at $100 \mathrm{~g} \cdot \mathrm{L}^{-1}$ or Transfilm at $50 \mathrm{~g} \cdot \mathrm{L}^{-1}$ for $5 \mathrm{~s}$. Herbicides were applied at $1 / 200$ of the labeled rate (dicamba $0.56 \mathrm{~kg}$ ae/ha or $2,4-\mathrm{D} 1.06 \mathrm{~kg}$ ae/ha). Values represent seven replications of each treatment. WAT $=$ weeks after treatment.

${ }^{\mathrm{y}}$ PROC GLIMMIX using a link = logit function for binomial distributions was used to analyze floral abortion data as proportion of the total number of reproductive organs. Back-transformed data [\% flower abortion $=$ odds $/(1+$ odds $)]$ are presented. Means for each cultivar and herbicide treatment within a column followed by the same uppercase letters and means within a row followed by the same lowercase letters are not significantly different using Fisher's protected least significant difference test, $P \leq 0.05$.

NS, ***, *Indicate nonsignificance and statistical significance at $P \leq 0.001$ or 0.05 , respectively. occurred as plants were transplanted or moved before and after treatment, allowing herbicide absorption.

While ML and WP treatments partially mitigated some of the adverse effects of simulated dicamba and 2,4-D drift, especially on 'FL' plants, they also had some shortcomings. For example, ML is the only product among the three tested that is labeled for use on food crops (caneberries and fruit trees) but not tomato. Because of incomplete mitigation of injury symptoms at the rates evaluated in this study, tomato plants exhibiting herbicide injury would most likely be nonsaleable for retailers. Also, fruit harvested from herbicide-injured plants may be considered unacceptable even though it has no detectable herbicide residue or the residue content is below the legal limit established by the Environmental Protection Agency. Furthermore, if tomato plants received multiple drift events, the film barrier on plant surfaces from these antitranspirant products may crack and be less effective with foliar expansion and stem growth. Others have shown that film-forming antitranspirants protected plants from abiotic stress temporarily (Anderson and Kreith, 1978; Englert et al., 1993; Hummel, 1990; Park et al., 2016; Plaut, 2008).

Despite incomplete early protection against herbicide drift on tomato plants, this study provides proof of concept that ML and WP antitranspirants can at least reduce visual symptoms from dicamba and 2,4-D drift injury. Future studies may also show that such film-forming antitranspirants provide partial protection from dicamba or 2,4-D drift injury on woody ornamental vines and shrubs, which may recover from injury with subsequent growth or pruning and become marketable or aesthetically pleasing in the landscape. Also, future studies may be warranted to investigate the use of higher rates of ML or WP and alternative application methods.

\section{Literature Cited}

Albrigo, L.G. 1972. Appearance and persistence of pinolene antitranspirant sprayed on 'Valencia' orange leaves. HortScience 7:247-248.

Alves, G.S., G.R. Kruger, J.P. da Cunha, D.G. de Santana, L.A. Pinto, F. Guimarães, and M. Zaric. 2017. Dicamba spray drift as influenced by wind speed and nozzle type. Weed Technol. 31:724-731.

Anderson, J.E. and F. Kreith. 1978. Effects of filmforming and silicone antitranspirants on four herbaceous plant species. Plant Soil 49:161-173.

Bauerle, M., J. Griffin, J. Alford, A. Curry, III, and M. Kenty. 2015. Field evaluation of auxin herbicide volatility using cotton and tomato as bioassay crops. Weed Technol. 29:185-197, doi: https://doi.org/10.1614/WT-D-14-00097.1.

Bennet, R.J. 1989. The effects of 2,4-D iso-octyl ester/ ioxynil herbicide in the liquid and vapour phases on the growth of tomato (Lycopersicon esculentum Mill.) plants. S. Afr. J. Plant Soil 6:24-31, doi: https://doi.org/10.1080/02571862.1989.10634474.

Bish, M., S. Farrell, R. Lerch, and K. Bradley. 2019. Dicamba losses to air following applications to soybean under stable and nonstable atmospheric conditions. J. Environ. Qual. 48:1675-1682, doi: https://doi.org/10.2134/jeq2019.05.0197.

Bradley, K. 2017. Off-target movement of dicamba in Missouri. Univ. Missouri Integrated Pest 
Mgt. 28 Jan. 2021. <https://ipm.missouri.edu/ IPCM/2017/8/Off-target_movement/>.

Cobb, A. 1992. Herbicides and plant physiology. Chapman \& Hall, London.

Coyne, D.P. and O.C. Burnside. 1968. Differential plant injury and yield responses of tomato varieties to 2,4-D. Univ. Nebr. Agr. Expt. Sta. Res. Bul. 226

Culpepper, A.S., L.M. Sosnoskie, J. Shugart, N. Leifheit, M. Curry, and T. Gray. 2018. Effects of low-dose applications of 2,4-D and dicamba on watermelon. Weed Technol. 32:267-272, doi: https://doi.org/10.1017/wet.2018.4.

Davenport, D.C., K. Uriu, and P.E. Martin. 1974. Effects of film antitranspirants on growth. J. Expt. Bot. 25:410-419.

Davies, W.J. and T.T. Kozlowski. 1974. Short and long-term effects of antitranspirants on water relations and photosynthesis of woody plants. J. Amer. Soc. Hort. Sci. 99:297-304.

Egan, J.F. and D.A. Mortensen. 2012. Quantifying vapor drift of dicamba herbicides applied to soybean. Environ. Toxicol. Chem. 31:1023-1031.

Englert, J.M., K. Warren, L.H. Fuchigami, and T.H.H. Chen. 1993. Antidesiccant compounds improve the survival of bare-root deciduous nursery trees. J. Amer. Soc. Hort. Sci. 118:228-235.

Funk, K.M. 1979. The effectiveness of Wilt Pruf, Vapor Gard, Exalt 4-10, and mulching for reducing winter desiccation of three taxa of broadleaf evergreens. MS Thesis, Kansas State Univ., Manhattan.

Gage, K.L., R.R. Drausz, and S.A. Walters. 2019. Emerging challenges for weed management in herbicide-resistant crops. Agriculture 9:180, doi: https://doi.org/10.3390/agriculture9080180.

Gale, J. 1961. Studies on plant antitranspirants. Physiol. Plant. 14:777-786.

Goreta, S., D.I. Leskovar, and L.L. Jifon. 2007. Gas exchange, water status, and growth of pepper seedlings exposed to transient water deficit stress are differentially altered by antitranspirants. J. Amer. Soc. Hort. Sci. 132:603-610, doi: https://doi.org/10.21273.JASHS.132.5.603.

Guan, L., R. Tayengwa, Z. Cheng, W.A. Peer, A.S. Murphy, and M. Zhao. 2019. Auxin regulates adventitious root formation in tomato cuttings. BMC Plant Biol. 19:435, doi: https://doi. org/10.1186/s12870-019-2002-9.

Han, J. 1990. Use of antitranspirant epidermal coatings for plant protection in China. Plant Dis. 74:263-266.
Hemphill, D.D., Jr. and M.L. Montgomery. 1981. Response of vegetable crops to sublethal application of 2,4-D. Weed Sci. 29:632-635.

Hummel, R.L. 1990. Water relations of containergrown woody and herbaceous plants following antitranspirant sprays. HortScience 25:772-775, doi: https://doi.org/10.21273/HORTSCI.25.7.772.

Jones, G., K. Norsworthy, T. Barber, E. Gbur, and G. Krueger. 2019. Off-target movement of DGA and BAPMA dicamba to sensitive soybean. Weed Technol. 33:51-65, doi: https://doi. org/10.1017/wet.2018.121.

Knezevic, S.Z., O.A. Osipitan, and J.E. Scott. 2018. Sensitivity of grape and tomato to micro-rates of dicamba-based herbicides. J. Hort. 5:1, doi: https://doi.org/10.4172/2376-0354.1000229.

Koske, T.J., A.L. Morgan, C. Overstreet, and D.M. Ferrin. 2009. Tomatoes. 20 Oct. 2020. <https:// www.lsuagcenter.com/NR/rdonlyres/069BCD8F9469-4843-9CF9-C4A7921BCED3/58635/1902 tomatoesHIGHRES1.pdf $>$.

Kreith, F., A. Taori, and J.E. Anderson. 1975. Persistence of selected antitranspirants. Water Resour. Res. 11:281-286.

Kruger, G.R., W.G. Johnson, D.J. Doohan, and S.C. Weller. 2012. Dose response of glyphosate and dicamba on tomato (Lycopersicon esculentum) injury. Weed Technol. 26:256-260, doi: https://doi.org/10.1614/WT-D-11-00073.1.

Missouri Department of Agriculture. 2017. 2017 Dicamba complaints in Missouri. 28 Jan. 2021. $<$ https://agriculture.mo.gov/plants/pdf/dicambamap.pdf $>$.

Mohseni-Moghadam, M. and D. Doohan. 2015. Response of bell pepper and broccoli to simulated drift rates of 2,4-D and dicamba. Weed Technol. 29:226-232, doi: https://doi.org/ 10.1614/WT-D-15-00106.1.

Mueller, T. and L. Steckel. 2019. Dicamba volatility in humidomes as affected by temperature and herbicide treatment. Weed Technol. 33:541-546, doi: https://doi.org/10.1017/wet.2019.36.

Nitzsche, P., G.A. Berkowitz, and J. Rabin. 1991 Development of a seedling-applied antitranspirant formulation to enhance water status, growth, and yield of transplanted bell pepper. J. Amer. Soc. Hort. Sci. 116:405-411, doi: https://doi.org/10.21273/JASHS.116.3.405.

Nordby, A. and R. Skuterud. 1974. The effects of boom height, working pressure and wind speed on spray drift. Weed Res. 14:385-395.

Ondi Enterprises. 2020. Moisture-Loc label. 1 May 2020. <https://conserveawater.com/wp-content/
uploads/2018/04/CAW_ML_5gal_051717_ PRINT-compressed.pdf $>$.

Park, S., S.A. Mills, Y. Moon, and N.L. Waterland. 2016. Evaluation of antitranspirants for enhancing temporary water stress tolerance in bedding plants. HortTechnology 26:444 452, doi: https://doi.org/Org/10.21273/HORTTECH. 26.4.444.

PBI Gordon, 2017. TransFilm. 1 May 2020. $<$ http://www.cdms.net/ldat/ldAIS002.pdf $>$.

Peterson, M.A., S.A. McMaster, D.E. Riechers, J. Skelton, and P.W. Stahlman. 2016. 2,4-D Past, present, and future: A review. Weed Technol. 30:303-345, doi: https://doi.org/10.1614/WTD-15-00131.1.

Plaut, Z. 2008. Antitranspirants: Film-forming types, p. 39-42. In: S.W. Trimble (ed.). Encyclopedia of water science. CRC Press, Boca Raton, FL.

Robbins, W.A. and W.S. Taylor. 1957. Injury to canning tomatoes caused by 2,4-D. Proc. Amer. Soc. Hort. Sci. 70:373-387.

Sosnoskie, L.M., A.S. Culpepper, L.B. Braxton, and J.S. Richburg. 2015. Evaluating the volatility of three formulations of 2,4-D when applied in the field. Weed Technol. 29:177-184, doi: https://doi.org/10.1614/WT-D-14-00128.1.

Sutherland, F. and D.R. Waters. 2002. Effect of film-forming polymers on infection of barley with the powdery mildew fungus, Blumeria graminis f. sp. hordei. Eur. J. Plant Pathol. 108:385-389.

Thompson, L.M.L. 1989. An investigation into the mode of action and selectivity of 3,6-dichloropicolinic acid. PhD Diss., Nottingham Polytechnic, UK.

Walters, B.R. 1992. The effects of three film-forming polymers, with and without a polyamine biosynthesis inhibitor, on powdery mildew infection of barley seedlings. Ann. Appl. Biol. 120:41-46.

Williamson, R.E. 1963. The effect of a transpiration-suppressant on tobacco leaf temperature. Soil Sci. Soc. Amer. Proc. 27:106, doi: https:// doi.org/10.2136/sssaj1963.03615995002700010 035x.

Wilt-Pruf Products. 2020. Wilt-Pruf label. 1 May 2020. <http://wiltpruf.com/wp-content/.uploads/ 2018/06/Wilt-Pruf-Gallon-Label.pdf $>$.

Zangoueinejad, R., M.T. Alebrahim, and T.M. Tseng. 2019. Evaluation of auxin tolerance in selected tomato germplasm under greenhouse and field conditions. Weed Technol. 33:815-822, doi: https://doi.org/10.1017/wet.2019.51. 